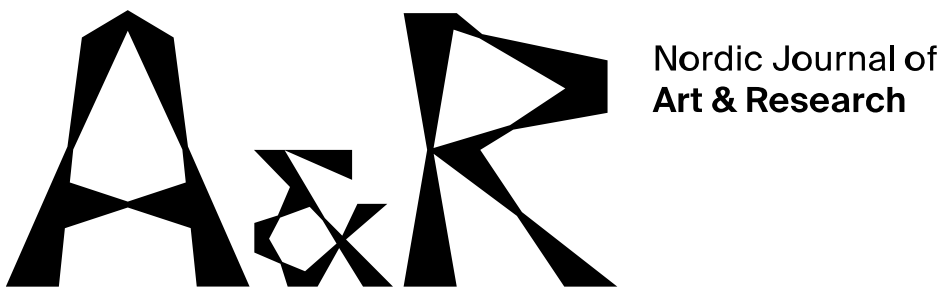

\title{
Dramaturgies of reality - shaping and being shaped by things
}

\author{
Camilla Eeg-Tverbakk ${ }^{1}$ \\ Oslo Metropolitan University
}

\begin{abstract}
New dramaturgy expands beyond the theatre and stage, working on the ways in which things in each time and space are organised and produce meaning. I link this to object-oriented ontology (Morton, 2013; 2016; 2018) and the ethics of relating to things (Benso, 2000) in my discussion of three works of art in public space: House of Commons (2015) by Marianne Heske, Movimento HO (2016) by Eleonora Fabião, and The Viewer (2019) by Carole Douillard. All three works temporarily introduce specific material into a public space, working with time to open up the 'thingliness' (Heidegger, 2001/1971) of the material, thus changing the dramaturgy of the place and how people relate to it. The works subtly introduce the potential of experiencing reality in new ways, changing narratives through a reciprocal process of shaping and being shaped by things. This is the result of the fact that every thing is always in motion, morphing without purpose or direction. 'Things rock', as Timothy Morton puts it. I use Morton's concept of tuning, and Silvia Benso's concept of tenderness when discussing how the materials in the three works - a house, bricks and human bodies - tune into a place, and how the viewer also tunes through what Benso calls 'tender touch', sometimes touching the material concretely, at other times touching the common ground or breathing the same air.
\end{abstract}

Keywords: dramaturgy, art in public space, object-oriented ontology, performance, ethics 
Camilla Eeg-Tverbakk. Dramaturgies of reality - shaping and being shaped by things

\section{Introduction}

Dramaturgy in an expanded field is fundamentally concerned with how things are composed in relation to each other as a way of structuring forms of narrative and the production of meaning. In theatre practice, dramaturgy has traditionally been the way in which coherence and logic are shaped within a narrative. In recent years, however, the concept of New Dramaturgy (Trencsényi \& Cochrane, 2014; Bellisco et al., 2011; Eeg-Tverbakk, 2018; Turner \& Behrndt, 2008; Romanska, 2016) has drawn on contemporary movements in philosophy to expand the methods and fields in which dramaturgy can be applied. This is related to an understanding that human perceptions of reality are not given, but are in fact dependent on the way that same reality is organised materially, culturally and conceptually. Through discourses on the Anthropocene, the post-human and post colonialism, we learn about other perspectives and ways of experiencing reality than just the (Western) human perspective. As a practising dramaturg in the interdisciplinary field of performance, I have been interested in exploring dramaturgies in public spaces; how the way things are placed, shaped and designed in relation to each other affects human movement, interactions and thus narratives of the real in specific time and places. To explore this area of dramaturgy, I look at art works that in different ways work temporarily with relations between things, places and human interaction.

There are numerous examples of artists who have worked on changing the perspective and experience of public spaces. There is a long tradition for site-specific art practices, which Miwon Kwon, among others, writes about in her book One Place After Another, Site Specific Art and Locational Identity (Kwon, 2002). Kwon traces the trajectory from site-specific art in the 1960s to its development into public art that engages more conceptually and relationally with public spaces, rather than merely aestheticizing them. She also address how site-oriented art increasingly engaged with audiences during the 1990s, through interactivity and participatory practices. Kwon describes relational and site-oriented art practices as 'collective artistic praxis', which does not aim for a consolidation of community as a unity, but for a performing together in an incomplete, open-ended, collective social process.

What happens if we include objects, things and materials in this social process, pairing it with the idea of a dramaturgy of the real? In his essay 'Dramaturgy in an expanded field', José A. Sánchez writes that dramaturgy is something that mediates between place (stage), action and drama (narrative). He points out that avant-garde movements in staged art practices have 'taken to the streets' (Sánchez, 2011, p. 41), not only using the street as stage, but also seeing theatre in the activities of the street, what he calls 'social spaces as theatre'. With reference to the sociologist 
Camilla Eeg-Tverbakk. Dramaturgies of reality - shaping and being shaped by things

Erwing Goffman and anthropologist Victor Turner, who both contributed to the development of the field of performance studies, Sánchez points to how social behaviour has been seen as performance. 'Victor Turner recognised in these dramas not a fixed space, but a space of change' (Sánchez, 2011, p. 44). Performativity, or the performative turn, applies to both Kwon's concept and the phenomenon of expanded dramaturgy that is Sánchez's concern. Performativity deals with the tension between reality and fiction, which is in continuous movement and transformation, offering a potential for change of perception and transformation of the real. If we add some of the main concepts of object-oriented ontology (OOO) to the mix, everything involved in social processes is in a state of constant transformation, revealing and withdrawing different sides of itself depending on what it stands in relation to. In the philosophy of $\mathrm{OOO}$, everything is regarded as objects/things (or material), including human bodies, thoughts, dreams, concepts, narratives, ideas, buildings, streets, wood, bricks, conversations, trees, rivers, etc. Graham Harman (Harman, 2002; 2010) is known to have coined the term OOO to denote a field of philosophy, which again refers to Heidegger's writings on the withdrawn in things (Heidegger, 2001/1971). I will primarily draw on the writings of Timothy Morton (Morton, 2013; 2016; 2018), another thinker within OOO. It should be noted that I prefer to use the word 'thing', in the way Heidegger defines things, in contrast to objects, as materials not yet defined and captured by language.

I will explore how three different works of art invite audiences to experience reality in ways than can open up unknown perspectives and perceptions, through the way the artists organise or re-organise public space and give the chosen materials (a wooden house, bricks and human bodies) agency to act. This entails the artist giving up levels of control and partly withdrawing from the situation. My first example is House of Commons (2015) by Norwegian artist Marianne Heske, who placed an architectural structure in Eidsvolls Plass in Oslo, right in front of the parliament building, which inserted a different narrative into the historical site of governmental practice in the Norwegian capital. The second example is a processual performance-installation, Movimento HO (2016), by Brazilian artist Eleonora Fabião. The piece was a collective action performed, among other things, by 4,700 bricks, three books, seven human collaborators, gallery visitors, the cultural centre's staff, a truck and removal workers. The piece exemplifies constant transformation through the shifting of shapes, narratives and actions aided by acts of listening, conversations, and cocreation. The third example is a performance-sculpture, The Viewers, by French artist Carole Douillard, which has been presented in many cities, but which I experienced as part of Oslobiennalen First Edition (2019-24). The piece uses human bodies as its material, becoming part of already existing assemblages of things in public spaces, 
Camilla Eeg-Tverbakk. Dramaturgies of reality - shaping and being shaped by things

entangling in new ways dramaturgically to create surprising narratives when the group of human bodies is encountered. All three pieces use materials that we normally think of as having a function that serves human beings, a house and bricks for instance, and even bodies, which we often think of as being a subject's property. Here, the materials escape their function, which is dance scholar André Lepecki's definition of things: 'whatever escapes instrumental reason, whatever exists outside logics of manipulation [...] whatever actively wants to run away...' (Lepecki, 2016, p. 29).

My dramaturgical practice is rooted in how materials move and relate to each other, framed by time and space. I have training in a movement-based theatre pedagogy (Jacques Lecoq) and worked as a dance dramaturge. Morton is also concerned with movement, more precisely with how things move by themselves. In his article 'Appearance is War', he states:

The kind of movement this essay is interested in is achieved by a body that's not only all by itself - it's also not going anywhere in particular. It's waving, undulating, vibrating. This undulation is why things can happen, which doesn't necessarily mean things going from A to B. (Morton, 2016, p. 167)

My method of exploration is to enter into a dialogue with the three works of art through a sensorial process of attunement (Morton, 2018) and tenderness (Benso, 2000), involving the movements of the body I call 'mine' when encountering the materials of the works of art and the places they become entangled with. I am interested in experiencing performative agency, the rocking (Morton, 2016), of the materials in the pieces: an old house made of wood, bricks, and human bodies. These three pieces then re-activate other materials at the chosen site and set things in motion. Something else happens here, which differs from what we know from most works of art in public space, where the place is either an aesthetic background or a given, more or less static, conceptual frame. In the three works of art used as examples here, the materials, or objects, perform agency that transgresses human (and artistic) intentions. The house, bricks and human bodies do not confirm the place, but co-create and move the surroundings beyond any vision or control of the artists. The three works activate and introduce a different sense of time through their material encounters. When writing about these encounters in hindsight, I rely on both my embodied and mental memories as object-things. In his book I Swear I Saw This (Taussig, 2011), the anthropologist Michael Taussig introduces doubt as a quality in his research, which is always part of any representation of something that happened 
Camilla Eeg-Tverbakk. Dramaturgies of reality - shaping and being shaped by things

in the past. How can we be sure we are transmitting any kind of 'truth' about what happened, and how can we be certain about anything in a world of floating things in transformation? Taussig's argument concerns how any form of documentation of an event will never be exact, but will always be a collection of impressions suggesting a world 'that does not have to be explicitly recorded and is in fact all the more "complete" because it cannot be completed. In pointing away from the real, they [memories, drawings, recordings, pictures] capture something invisible' (Taussig, 2011, p.13). In the case of Fabião's piece Movimento HO, I have only experienced the work through documentation and in-depth conversations with the artist. I have, however, encountered one of the bricks, which is quite different from a Norwegian brick. The Brazilian one is perforated with holes to keep the inside of a room cool and ventilated. A Norwegian brick is solid in order to create a barrier against the cold and also have the ability to store heat.

\section{0}

Object-oriented ontology defines reality as something ungraspable in its entirety. No one can ever get a grip of the real. Thus, a human perspective of reality is partly a construction and open for interpretations and re-constructions. The idea is that a thing always has a hidden side and a side that is revealed to us through perception formed by sensory relations. There is always something withdrawn in things. This is because every thing holds a capacity for movement and transformation depending on what other things it connects to/with at a given moment. As human-things, we are never able to grasp this horizon of potentialities. The only way we can try to encounter other aspects of reality in things is through sensory encounters, relating to other sides of things, and perhaps altering the known dramaturgy of the real as we know it. However, in the process where other realities are shaped temporarily, something else withdraws. We can never perceive the totality of the potential horizons in things. Timothy Morton calls this the illusion of things, or 'realist magic' (Morton, 2013).

Withdrawn doesn't mean hard to find or even impossible to find yet still capable of being visualized or mapped or plotted. Withdrawn doesn't mean spatially, or materially or temporally hidden yet capable of being found, if only in theory. Withdrawn means beyond any kind of access, any kind of perception or map or plot or test or extrapolation. (Morton, 2013, p. 54)

Morton's concept of mystery is linked to the idea of the withdrawn side of objects and things. He equates the withdrawal of things with the unspeakable quality of them as a 
Camilla Eeg-Tverbakk. Dramaturgies of reality - shaping and being shaped by things

secret they carry. The claim that real things carry magic and mystery questions the idea of realism as a concept of truth, and the conceit that there are real things at all. The point is that the perceived dichotomy between real and non-real (fiction or mystery) collapses within object-oriented ontology. Every thing always has a side that is known and a side that is unknown to the perceiver as much as to the thing itself. Morton writes about the traces and footprints that things leave (causality), which he argues belong to aesthetics. In his view, art is the object in Western culture, which we relate to without thinking of its utility value, allowing the unknown to allure us into a relation with it. This is why he says that art attunes humans to other possible, more ecological futures (Morton, 2018). There will always be a level of interpretation in the way we relate to things, and, as Morton explains, interpretation is connected to conceptualisation, thus creating what he calls 'real illusions' when seeing something we think is real. However, '[e]very seeing, every measurement, is also an adjustment, a parody, a translation, an interpretation. A tune and a tuning' (Morton, 2013, p. 33).

In the following I will use Morton's ideas about 'rocking' (Morton, 2016) and 'tuning' (Morton, 2018) as a way of understanding how art and the aesthetic realm give birth to new formations. These concepts will also be discussed in relation to Italian philosopher Silvia Benso's (Benso, 2000) notions of tenderness as a mode of accessing and opening up the 'thingliness' in things, objects and materials. She writes about the way humans can ethically relate to objects to access their otherworldliness through tender touch, which reminds humans of their own mortality. Both Morton and Benso open ethical perspectives on how relations between humans and other things can unfold, and how humans and other things shape each other's realities reciprocally in a constant process of movement. The common ground between these two thinkers is in the unknown and withdrawn in things; the other of the other representing the ultimate alterity, which Benso suggests with reference to Emmanuel Levinas. My argument is that there are dramaturgical possibilities for an artist to open up for other perceptions of realities by letting things happen, rather than making things happen, thereby expanding our relationship to objects and the hierarchical position of humans in the Anthropocene. Perceptions of the real take form through the assemblages, co-creation, and entanglements of things, including humans, and how they are organised in relation to each other.

Alreadyness hints at our tuning to something else, which is a dance in which that something else is also, already, tuning to us... (Morton, 2018, p. 118) 
Camilla Eeg-Tverbakk. Dramaturgies of reality - shaping and being shaped by things

\section{House of Commons}

The image of House of Commons (figure 1.) is funny, uncanny and disturbing. As an inhabitant of Oslo, I often cross this square, which is normally an open space in front of the parliament building known as a place where protesters with different causes gather, or where people pass through on their way to their next appointment, or simply sit chatting on the benches. Entering the square when House of Commons was visiting felt like a whole different kind of protest. Silently, without words, but at the same time loudly through its foreignness, the house stood there tuning into its new environments. I had to stop and consider which way to move around the house, pausing and wondering if I should go inside. Standing like that in a moment of tuning, I became aware of the breathing lungs in the body I call mine, my feet on the ground, and the cold, wet air brushing against my face. Two bodies facing each other, one almost 200 years old, the other around 50 . I was enchanted by the old, unfamiliar house. Then, entering through the small door, I felt like stepping carefully, the building seemed fragile. Walking inside the old house felt like being on a journey through time, visiting from a different reality. There was old, partly stripped wallpaper on the wooden walls, glass from smashed windows, empty cupboards in the kitchen area. The old wooden planks on the ceiling and walls called for a different time spent together. The house was changing the dramaturgical time of the square, the event time, asking people and buildings questions about existence. Questions such as what a life is and consists of, about the contrast between something maintained and something forgotten, about class, power and productivity. Encountering and listening more tentatively to things entails a demand to slow down, take time and simply stay longer with them. It is something offered to contemporary city life that is ruled by efficiency, where even the subject has utility value. I was told that a family of eight people once lived in the house, which originally stood in Hobbøl some 100 kilometres south of Oslo. It was to be demolished to make way for a new road when the artist Marianne Heske asked if she could have it. The dramaturgy of the house represents both a journey through time and a class journey: from Hobbøl to Oslo, confronting the power gathered in the parliament building. Dramaturgically, the drama is set in the space between the buildings, between the ruling class and the working class, between those who rule and those who are ruled over. 


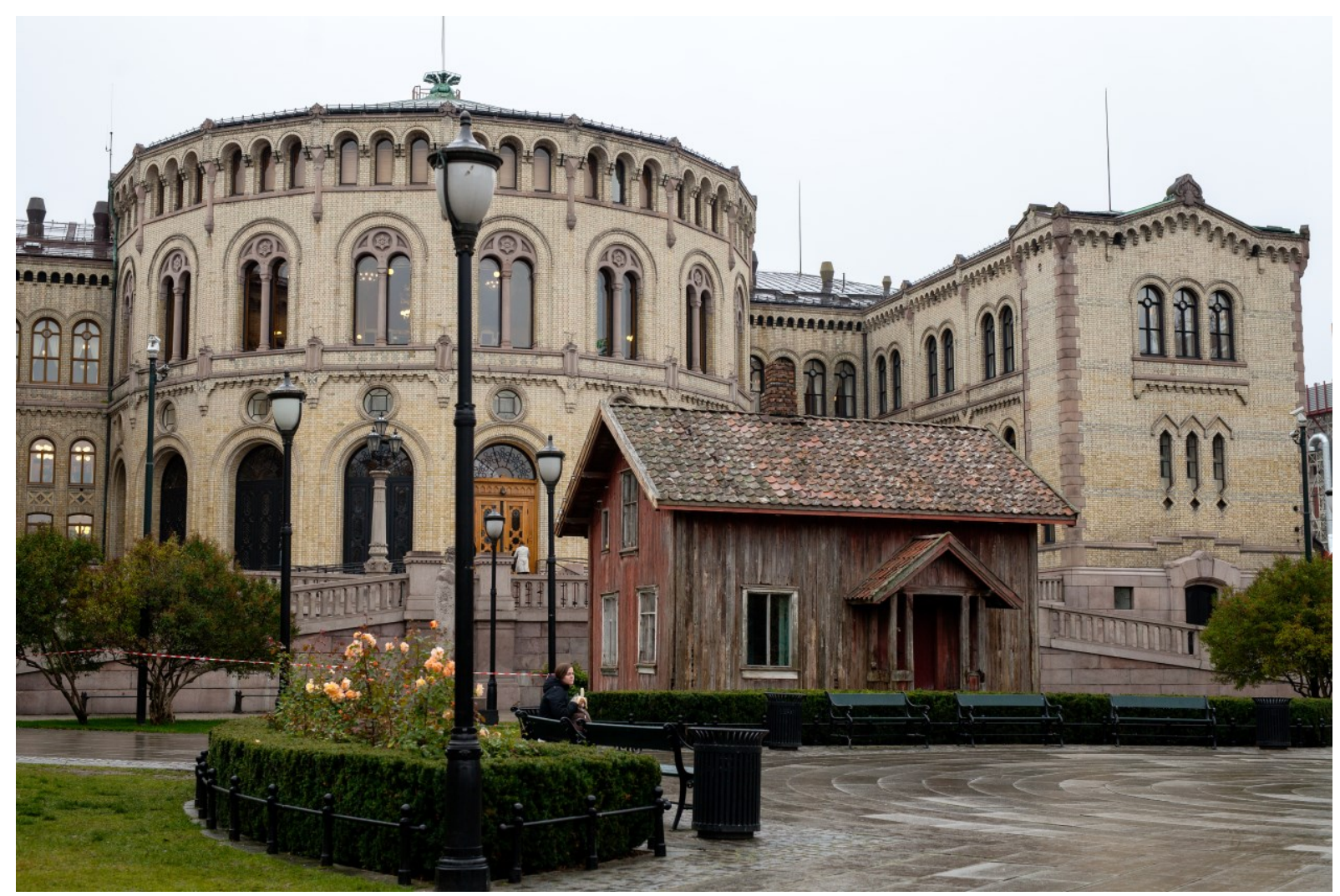

Figure 1. Marianne Heske, House of Commons (Oslo Pilot, 2015) Photo: Niklas Lello ()

This piece re-organises and changes our everyday reality as we are used to knowing it. But it also re-introduces another experience of reality. The house changes the dramaturgy of the square: how people move and experience the place. The house tells silent stories, it triggers sensorial memories and experiences in the present, and it changes the typography of the place for a time. The house performs its thingness, to use Heidegger's concept. So what does the house do in this context? How does it function here?

If we think of Heidegger's jug (Heidegger, 2001/1971), this house can in the same way be seen as a vessel where the thingness of the house lies in its ability to be filled, and how it shares what it has been given (the ways it has been shaped through time and encounters) in new constellations with other bodies, other houses, other trees etc. In these encounters, new realities are formed, re-formed and deconstructed. It is not so much about the stories that lie inherent in its walls but rather about the void that the physical materials frame. The void can be understood as 'framed reality'. Meanwhile, the experience of a reality is never stable but is constantly shaped and reformed in movement. The void that this house brings to the place can be filled by memories brought by visitors that are triggered in this specific encounter, by ideas and reflections taking place in the present, and by the way the 
Camilla Eeg-Tverbakk. Dramaturgies of reality - shaping and being shaped by things

material directs physical movement between buildings and in public space. This stands in contrast to the parliament building, which is a busy place of work for politicians in positions of power. That building has a purpose and important function in the social structure and is thus much more complicated to tune into.

Marianne Heske's House of Commons cannot be reduced to 'a house' or 'a collection of planks', it is much more than that. It exists as a thing beyond our experience, perception and knowledge of it. This is why the house can be likened to Hediegger's vessel holding the void as a gift, something we can enter into a complex relation with - and spend time in. This is contrary to capitalism, which wants us to spend a short time with things, thus objectifying them. I suggest spending time in/with the house, without words, while paying attention to how the body reacts and connects with the materiality of the house and how it affects our thinking, dreaming and memory. The way we relate to a thing or material affects its reality and how it, in turn, changes the reality it is part of. The reality of any object, thing or entity is never fully known, neither by itself nor anything else. The reason for this is that its reality shifts as a result of what relates to it in a specific way, place, and time. The old house changes dramaturgically when it is placed at Eidsvolls Plass. It is transformed from being an old house standing in the way of road building, to revealing other sides of itself: its beauty, fragility and thingliness in front of the parliament building.

Art is important to understanding our relationship to nonhumans [...] The aesthetic experience is about solidarity with what is given. It's a solidarity, a feeling of alreadiness, for no reason in particular, with no agenda in particular - like evolution, like the biosphere. (Morton, 2018, p. 121)

Heske's house has a very different reality when it is an art object in Oslo, housing visitors in brief encounters who subsequently return to warm houses and flats elsewhere, from the reality of a poor farming family of eight people living there without any other place to find shelter. Acknowledging and respecting the unknown aspect of objects and things seems to be an ethical way of relating to both sentient and non-sentient beings. It calls for curiosity, a careful approach and listening. It avoids colonising by letting go of the power of definition, ownership, or using the object to strengthen the self. Object-oriented ontology (OOO) argues that objects are separate, independent entities. However, they always stand in relation to other objects, and cannot come into being or into a field of perception without these connections. 
Camilla Eeg-Tverbakk. Dramaturgies of reality - shaping and being shaped by things

\section{Movimento HO}

The Brazilian artist and theorist Eleonora Fabião calls her performance Movimento $\mathrm{HO}$ a collaborative action. In the piece, the interdependence between things is exemplified in a poetic and inspirational way. In this performance and moving installation, the relationship between things (and especially the relationship between human beings and things) is explored in a collaborative way, not only between a group of humans - as a practice of democracy - but also between humans and things, allowing the things to affect the piece as much as the humans do. It is an example of an active interrelation between bodies, thoughts, conversations, building and bricks.

Fabião framed her performance in the following way:

To occupy, for 7 days in a row, with 4,700 bricks, 3 books and 7 people part of the ground floor and surroundings of the Centro Municipal de Arte Hélio Oiticica (Municipal Art Center Hélio Oiticica). To turn off the electric power in the galleries (no lights, no air conditioning), To open all doors and windows, and to paint one wall in $100 \%$ yellow.

From Monday to Sunday, bricks, books and people will move and be moved. Compositions will be made and unmade, spaces will be formed and unformed. Help from whoever wants to help will be fully accepted. We will construct, keep constructing, keep learning how to construct. In the middle of the week a conversation circle will be opened.

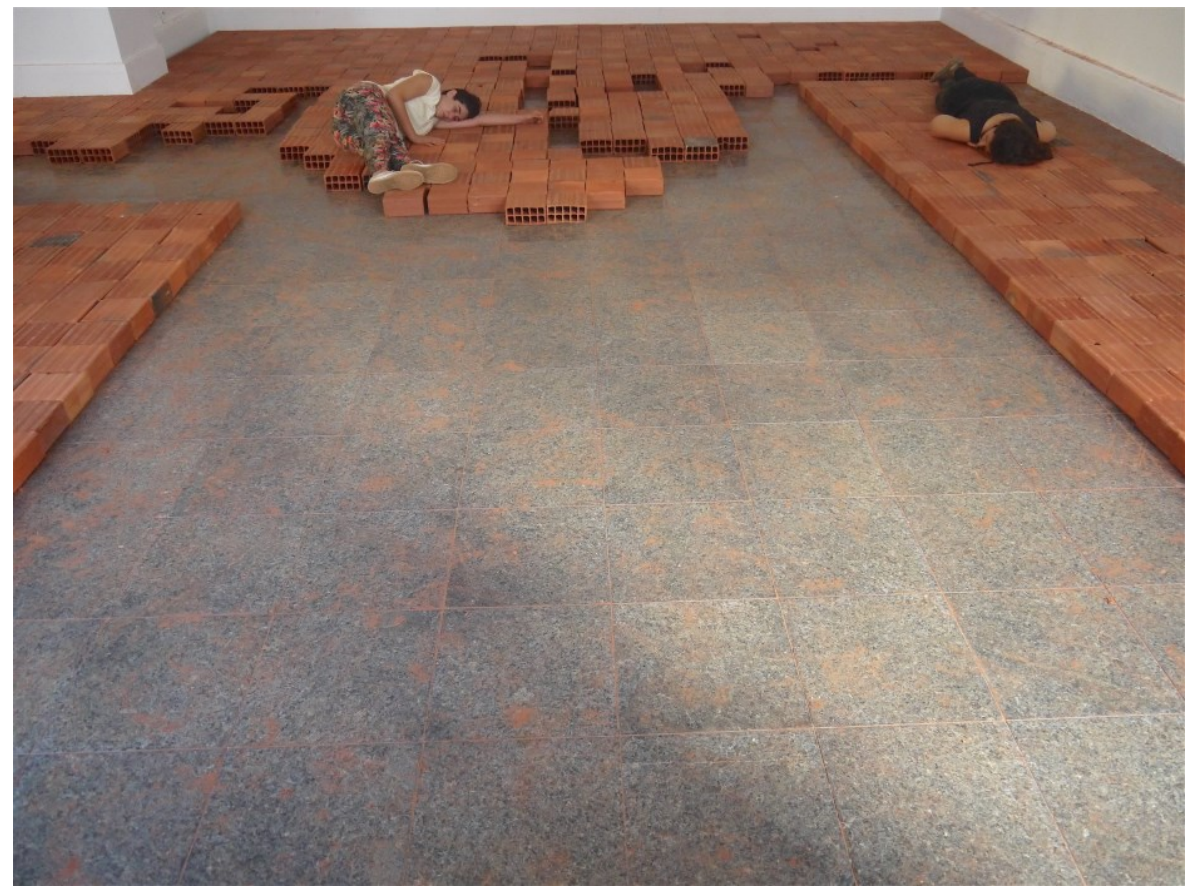


Camilla Eeg-Tverbakk. Dramaturgies of reality - shaping and being shaped by things

Figure 2. MOVIMENTO HO / HO MOVEMENT, photo Felipe Ribeiro and André Telles, courtesy of the artist, Eleonora Fabião and collaborators, Hélio Oiticica Municipal Art Center, Rio de Janeiro, 2016

This work is an example of how relating to material becomes a sensory experience. A listening practice is not only about using our ears, but listening with our skin, muscles, sense of smell and taste, and nervous system. The participating bodiessubjects-things needed to learn the nature, or the thingness, of the bricks and how they affected the human bodies carrying, lifting and stacking them. Fabião writes:

They [the bricks] absorb water tremendously - hands get very dry and it is necessary to drink about three glasses of water every hour and a half. They have great adherence, capacity of accommodation and mechanical resistance - rarely break but shed a good amount of dust. (Fabião, 2018, p. 58)

In her book The Face of Things, A Different Side of Ethics (Benso, 2000), Italian philosopher Silvia Benso is concerned with 'tenderness' as an ethical way of relating to things. According to Benso, things are 'free', while objects are 'captured'. Benso picks up on Heidegger's claim that the thingness of things has been forgotten, overlooked by science, and that the nature of things is never seen nor heard. Benso is interested in the ethical call of things and what she calls the 'faceless faces of things' or the 'faciality' of things, referring to the ethics of Emmanuel Levinas. Benso takes the call of the other to include the otherness of others, namely things, which she claims represent the ultimate alterity. One of Benso's key concerns is that things have a call to be treated with tenderness. Tenderness would be a response to the alterity of things, alterity being a gesture of self-giving. Things possess a reality she says, which can be experienced but not possessed through a 'touching mode of tenderness'. Tenderness is practised through touch. 
Camilla Eeg-Tverbakk. Dramaturgies of reality - shaping and being shaped by things

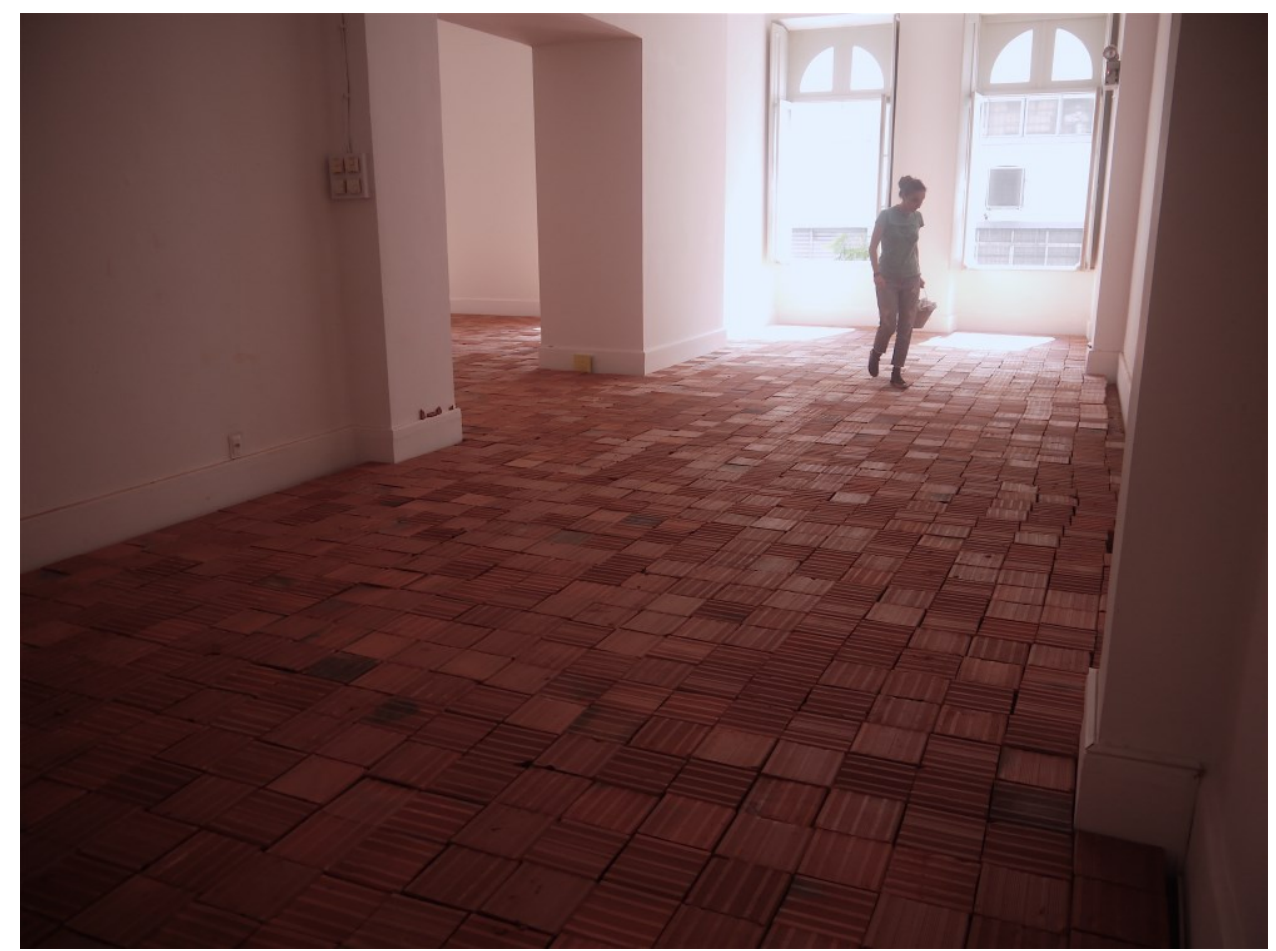

Figure 3. MOVIMENTO HO / HO MOVEMENT, photo Felipe Ribeiro and André Telles, courtesy of the artist Eleonora Fabião and collaborators, Hélio Oiticica Municipal Art Center, Rio de Janeiro, 2016

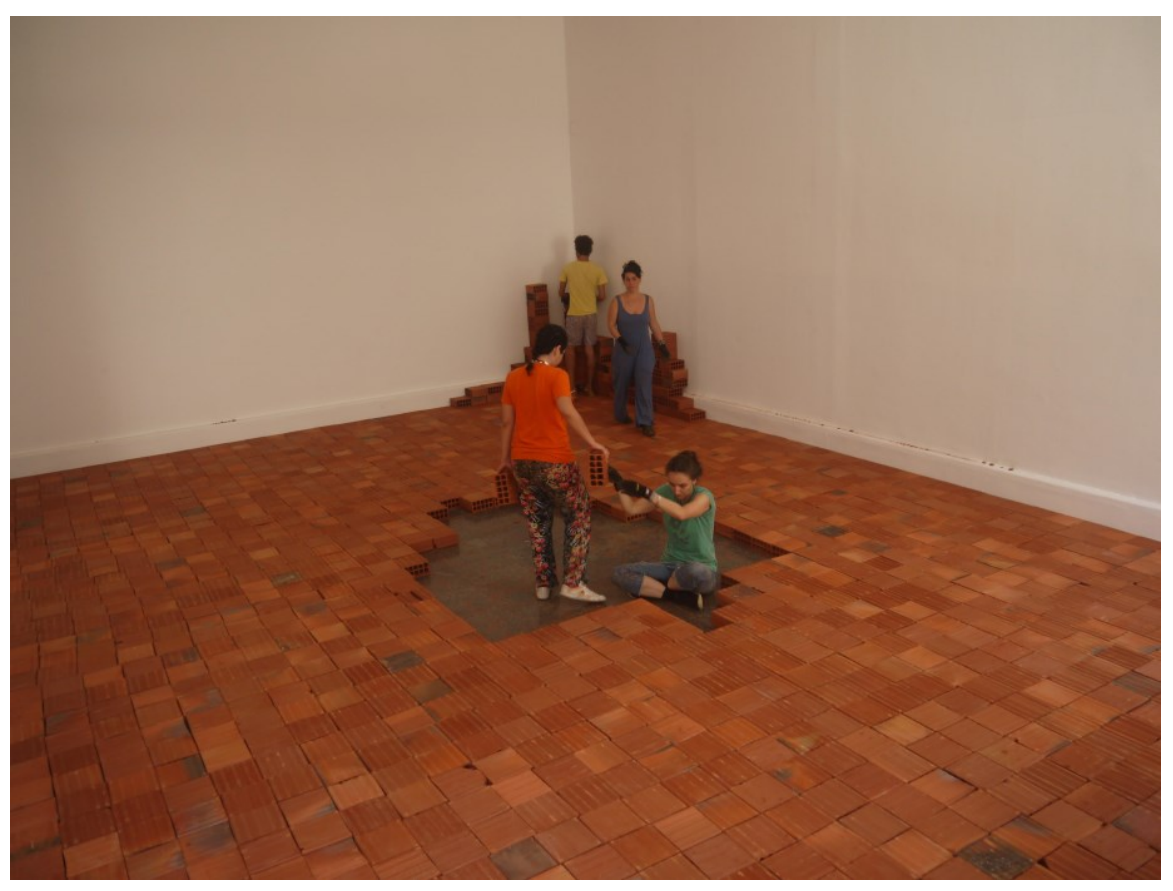

Figure 4. MOVIMENTO HO / HO MOVEMENT, photo Felipe Ribeiro and André Telles, courtesy of the artist Eleonora Fabião and collaborators, Hélio Oiticica Municipal Art Center, Rio de Janeiro, 2016

Some of the pertinent questions raised by Movimento $\mathrm{HO}$ were about understanding what the bricks need, and how bodies (people) can collaborate with the bricks. Not 
Camilla Eeg-Tverbakk. Dramaturgies of reality - shaping and being shaped by things

just planning, directing, deciding, shaping - but seeing what the bricks need and can do in the space. The goal was not to establish a permanent form, since that would turn the bricks back into being useful or having a purpose serving a cause, thereby giving it directionality, with reference to Morton's idea of how objects rock in a constant movement without going anywhere. Rather, Fabião explains how, on each of the seven days of the project, each construction of the bricks was already a ruin, built to be unbuilt. Eleonora Fabião speaks of performance, which is a temporary art form, as 'preserving life', and says that what performance does is to 'produce strangeness'. She uses the verb - 'to strange'. Doses of strangeness are vital to life, she says, and 'stranging' the bricks means relating to them in other ways than we would immediately imagine, which represents the normative utility value of bricks. Fabião claims that the artist's task is to change the value of things, in order to produce new modes of subjectivity.

Knowing the tenderness with which the artist always performs in art and life, I am fascinated by the images of the action, which in themselves are remains, memories, or dust. The images bring out a certain agency of the bricks, it is the bricks that are performing. The people are simply helping them to perform and to find other ways to exist in order to be able to produce other or unexpected realities (from a brick perspective). To produce strangeness is to care - to take care of what is needed in a specific circumstance. Fabião stresses the need to be precise in what action is needed in a specific public space. 


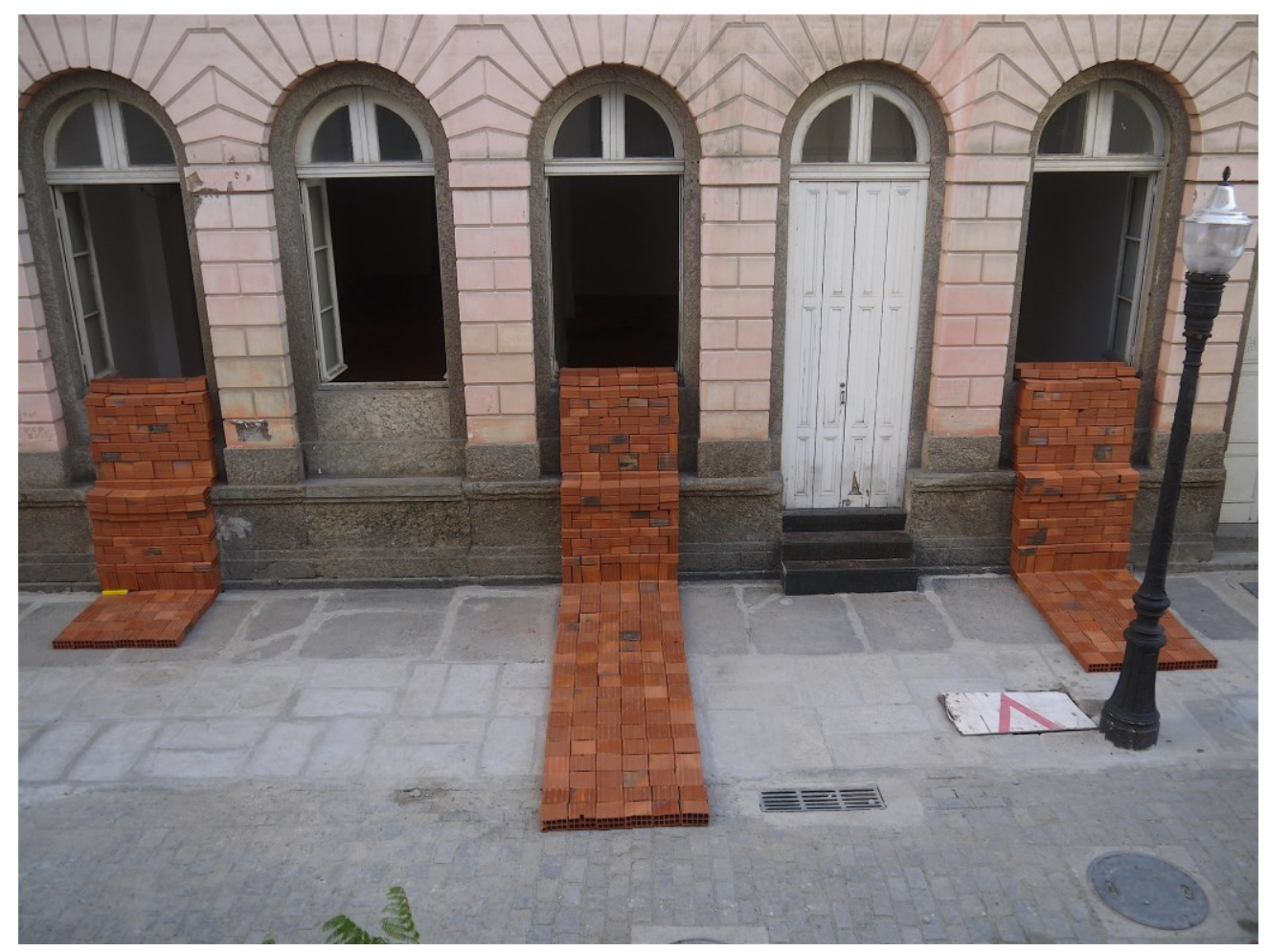

Figure 5. MOVIMENTO HO / HO MOVEMENT, photo Felipe Ribeiro and André Telles, courtesy of the artist Eleonora Fabião and collaborators, Hélio Oiticica Municipal Art Center, Rio de Janeiro, 2016

What is this? A sculpture that does not settle? A performance? It is a practice of urgency. People and bricks are moving, but through their movements, they are also dancing with the space. Nothing is fixed but is in a vibrant dynamic relationship. It is a matter of circulating questions, not answers. Circulating unanswered questions opens spaces for staying in/with the unknown. The unknown is what is not yet shaped, and, again, through patience and tenderness, it may be possible to sense or to stay with the not yet articulated, or the potentialities inherent in things. 
Camilla Eeg-Tverbakk. Dramaturgies of reality - shaping and being shaped by things

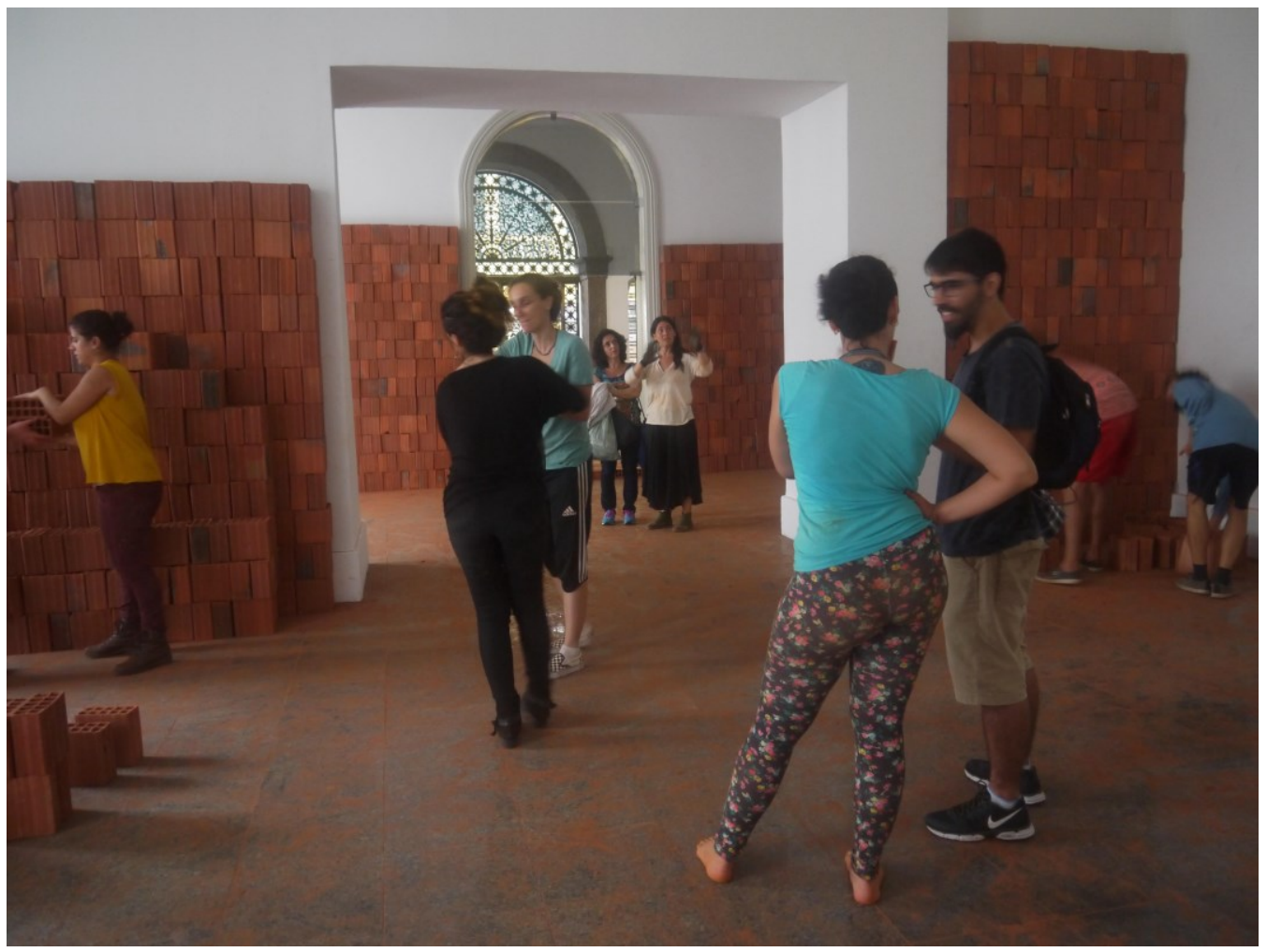

Figure 6. MOVIMENTO HO / HO MOVEMENT, photo Felipe Ribeiro and André Telles, courtesy of the artist Eleonora Fabião and collaborators, Hélio Oiticica Municipal Art Center, Rio de Janeiro, 2016

The piece Movimento $\mathrm{HO}$ is an investment in things, where bodies, spaces and bricks are co-partners, creating each other in the moment of interdependency and assemblage. Its gestures offer, both to human bodies and bricks, their thingliness as a way of co-existence. André Lepecki writes about the ways our commodified capitalist reality turns subjects and objects into apparatuses 'that subjugate and diminish our own capacity to produce non-subjugated subjectivities' (Lepecki, 2014). Subjectivity itself is becoming a kind of objecthood he writes, through the way objects control us and our capacity to produce and deliver; that has become our utility value. The action of Movimento $\mathrm{HO}$ is also about letting the bricks be something other than their 'proper use' - bound to capital. Perhaps, says Lepecki, the counter force of objects lies precisely in merely being a thing. This work is a laboratory for democracy and how to relate collaboratively to objects. On the last day, the bricks were removed - leaving only 'performance powder'. 
Camilla Eeg-Tverbakk. Dramaturgies of reality - shaping and being shaped by things

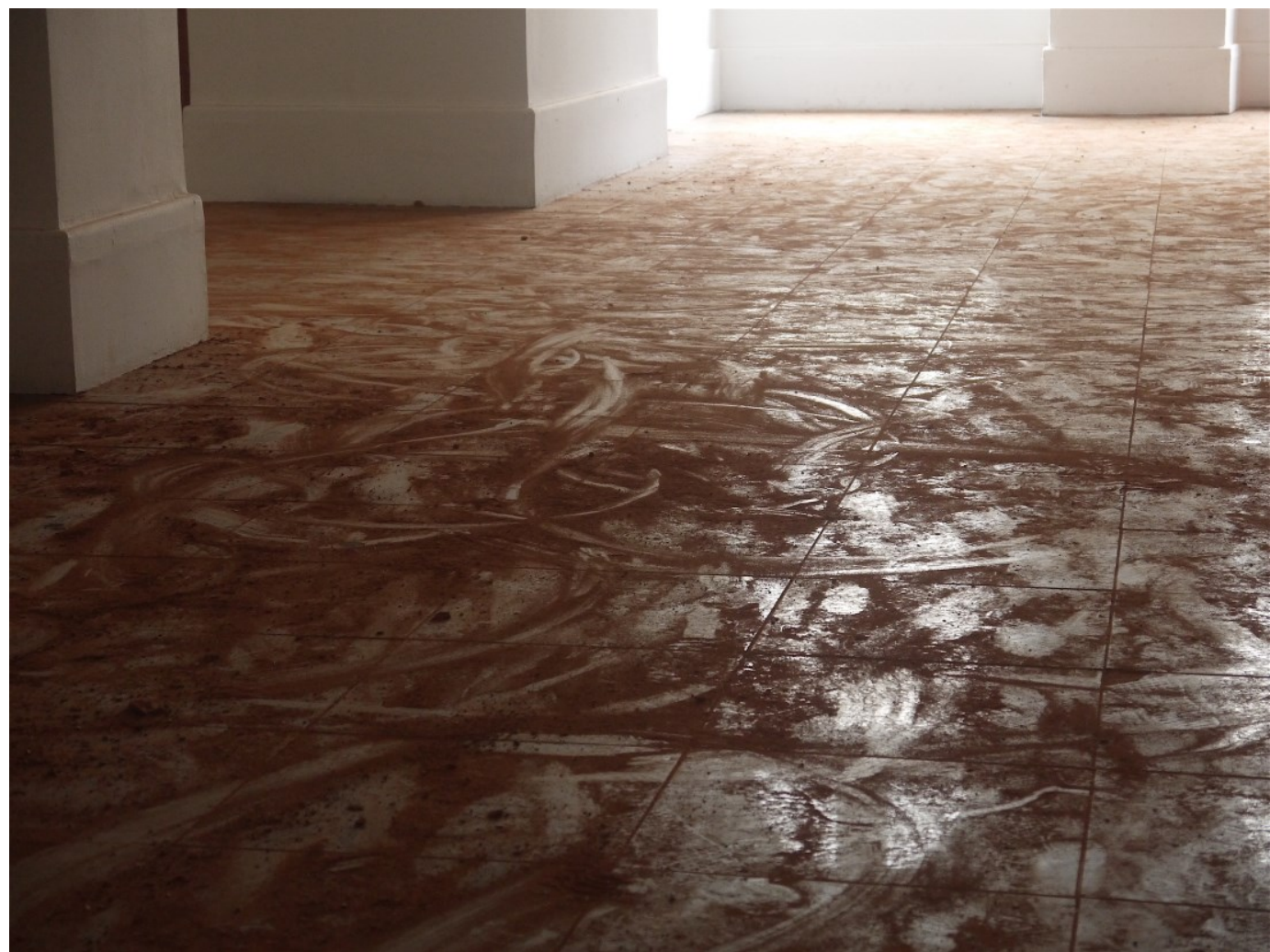

Figure 7. MOVIMENTO HO / HO MOVEMENT, photo Felipe Ribeiro and André Telles, courtesy of the artist Eleonora Fabião and collaborators, Hélio Oiticica Municipal Art Center, Rio de Janeiro, 2016

It is through tender touch, patience and humility in relation to things that we can access the metaphysical claims Silvia Benso, who describes attention as an exercise in patience, which is fundamentally about humility. Attention waits for the other to make a move. It is a movement of humility where the will to power is deferred. Attention takes place in a mode of waiting where you don't know what you are waiting for. It requires abandonment of the 'l', and of subjectivity as we know it, in order to transcend the binary relationship between self and the other.

A thing is richer than the sound, the smell, the taste of it, which the 'l' may - and does indeed - enjoy. It contains memories of an unreachable past, of the ancestral dance of the earth and the elements, of the eternal play of light and darkness, of being, but always as a beyond-being. (Benso, 2000, p. 137)

Here, we are reminded of Heidegger's formulation about the performativity of things: not to be, but to gather. What Silvia Benso means by being in a relation with things is being part of a reciprocal exchange and circulation. 'To hear the language of things means to enter the spaciousness of things, to let them be as things, and thus to become thingly' (Benso, 2000, p. 154). Tenderness is the ability to tune in, always in 
Camilla Eeg-Tverbakk. Dramaturgies of reality - shaping and being shaped by things

the present, never stable, always questioning and fragile. The ethics this project aims for are about exploring how an active relationship between human bodies and other things leads to the emancipation of both subjects and objects 'as a way of releasing objects from existing in a state of constant utilitarianism and subjects from the exhausting exercises of their egos and ego-existence' (Fabião, 2018, p. 66).

On the last day of the performance, the bricks from Movimento $\mathrm{HO}$ were returned to the social realm. They were used to build the fourth floor, housing a library, of a women's house in one of the favelas of Rio de Janeiro.

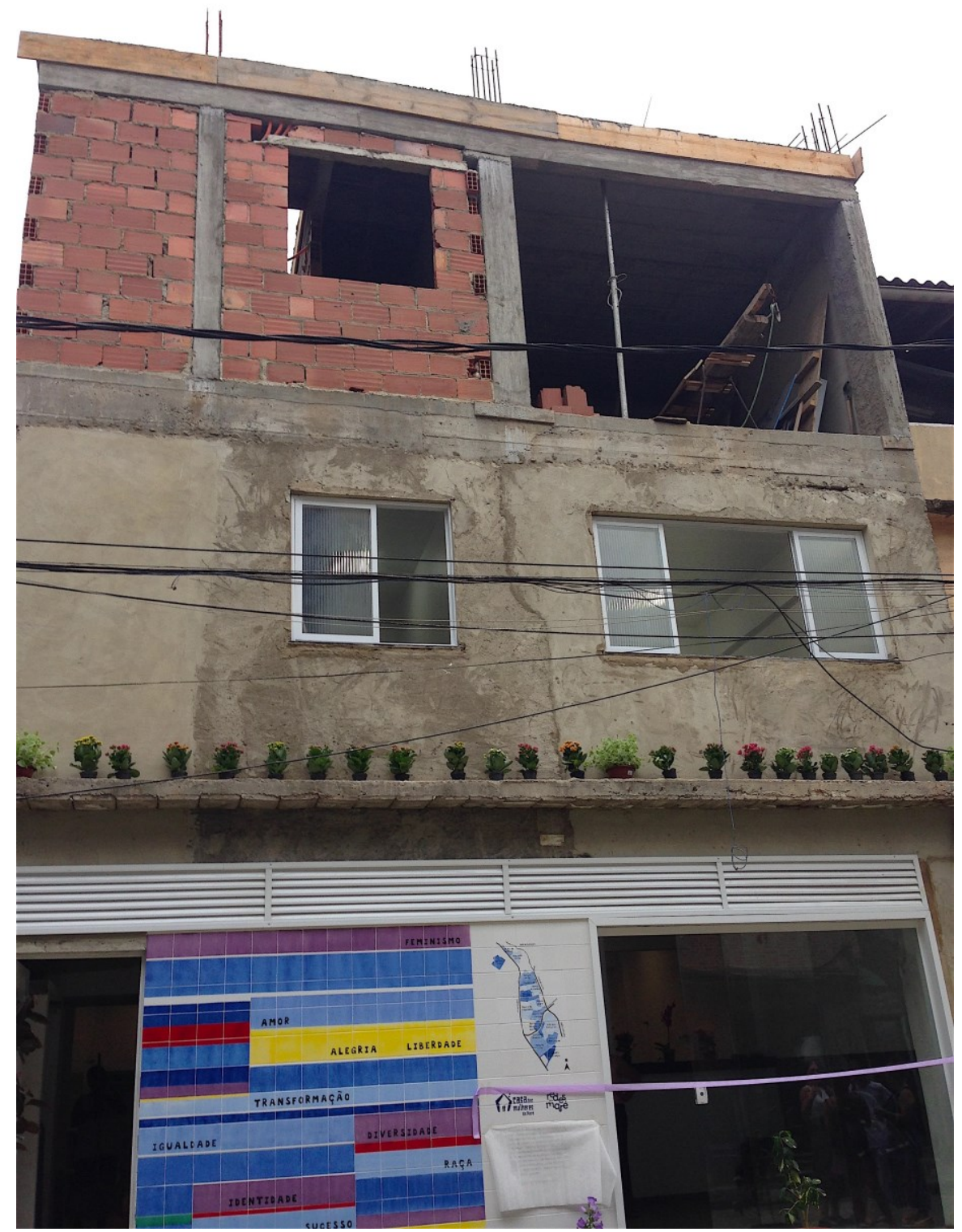

Figure 8. MOVIMENTO HO / HO MOVEMENT, photo Felipe Ribeiro and André Telles, courtesy of the artist Eleonora Fabião and collaborators, Hélio Oiticica Municipal Art Center, Rio de Janeiro, 2016 
Camilla Eeg-Tverbakk. Dramaturgies of reality - shaping and being shaped by things

From the programme description of Fabião's project Movimento HO:

On the last day the bricks and the books will be transported to the Casa das Mulheres da Maré (Women's House at Maré), a project of the NGO Redes de Desenvolvimento da Maré (Networks of Maré's Development Non-governmental Organization). The bricks will become the fourth and last floor of the house, and the books will become part of the library.

The notion of tenderness might be mistaken for focusing solely on a peaceful encounter with things, which is naturally problematic, especially with regard to art practice. A relationship is never stable, it is constantly in flux, moving through different emotional states and feelings such as love, hate, attraction, repulsion, or indifference: feelings that may result in a soft touch, but at other times violations or great distance. As Benso writes about it, tenderness deals with violence through endurance. It cannot overcome violence and ego-logics, but tenderness can halt or postpone violence, she argues. If it keeps doing this patiently, destruction may eventually fade away. Violence can redeem itself by becoming responsive to the ethical demands of things, which include its silent presence.

\section{The viewers}

In this context, my interest in Carole Douillard's performative work The Viewers (figure 9.) is in seeing the assemblage of bodies as a material that evokes a sensation of materiality in relation to my own body. It is a tuning, to use Morton's concept, where the group of bodies that constitutes the work of art tune into each other, and, as a group, they also tune into the surroundings. Simultaneously, my body starts to tune into their still movement as I decide to give them focus and spend time with them. The interesting thing about Morton's concept is that it implies a spectrum of possibilities. To him, art offer human beings a space in which to experience the constant undulation of the universe. Because it is not going anywhere, and because it can offer modern humans stillness and quiet. A stillness that is alive and quivering (Morton, 2016, p. 168), of which The Viewers is a good example. 
Camilla Eeg-Tverbakk. Dramaturgies of reality - shaping and being shaped by things

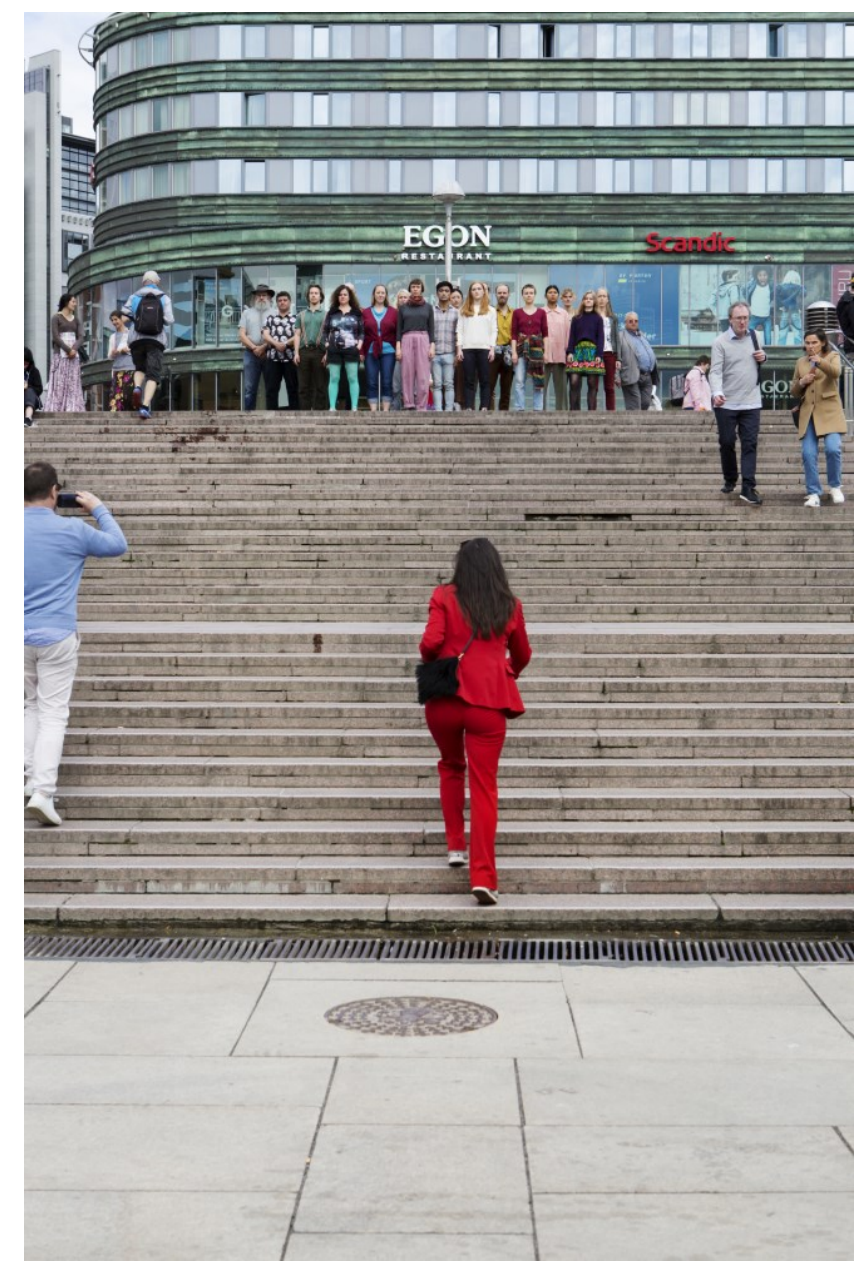

Figure 9. Carole Douillard: The Viewers, 2019, a performance at Oslo Central Station. Photo: Inger Marie Grini. Courtesy of Carole Douillard/ Oslobiennalen First Edition 2019-2024

I encountered the assemblage of bodies standing in silence at the top of a busy staircase outside the central train station in Oslo. A number of bodies, different in size, shape, age, colour and clothing, are gathered in a group formation. They stood still, quietly, for hours on end in specifically chosen places throughout the city. ${ }^{2}$ The meditative focus of the group stands in stark contrast to the hectic activity of people moving from $A$ to $B$ (with a purpose) in a western city centre. The artist Carole Douillard has worked with the individual participants and instructed them in how to

2 In addition to the central station area, The Viewers stood in Ekebergparken, Frognerparken, Birkelunden, Grønland torg, Jernbanetorget, Nobels Fredssenter, Rådhusplassen, Operahuset, Universitetsplassen, in front of the Y-block, Regjeringskvartalet in front of the $\mathrm{H}$-block, and Youngstorget in Oslo between May and October 2019. 
Camilla Eeg-Tverbakk. Dramaturgies of reality - shaping and being shaped by things

meet other people's gaze, how to focus and be present without creating narratives or meaning. Again, I become aware of the tempo of my body and how it is constantly affected by city life, producing a certain level of stress. Encountering this assemblage of bodies is a physical confrontation with a different sense of time, asking me to slow down. I can feel the bodies of The Viewers as an energetic pressure on my skin, and I have to work on my breath to get my lungs to slow down and relate differently to the air, inhaling more deeply and exhaling more slowly. The Viewers invites me to hang out with them without purpose, without producing knowledge or meaning, taking time to tune into the surroundings, the place in which I exist in each moment. Returning to Silvia Benso's concept of tenderness, the group of bodies do not just touch the paved ground in the place they are standing, they also touch the shared space through their breathing and their perforated skin. The skin is a porous membrane exchanging energy with the surroundings when someone rushes by, with traffic noise, the vibrations of the trams and buses, and much more that moves the bodies. Time is crucial here as their thingliness appears through waiting, patiently with humility, not knowing what they are waiting for (Benso, 2000).

In his text 'Appearance is War' (Morton, 2016), Timothy Morton is concerned with pointing out how everything is always in motion, and that we cannot know anything exactly because everything always moves, wiggles, undulates, rocks. Thus, ambiguity is a positive aspect of life in things, existence cannot be clear or defined: 'to exist means to be profoundly ambiguous' (Morton, 2016, p. 169). The looks on the faces of the group express this ambiguity, this 'just life', where it becomes difficult to understand, and even uninteresting to know what the purpose might be. Through working on the vibration of stillness, the thingliness of the bodies is given time to be presenced. The bodies stand still in the same way as the buildings do, like other slower subjects that are often objectified in society: the poor, the homeless, the impaired, drug addicts and the elderly. Awareness rocks, says Morton, and continues: 'Awareness oscillates or undulates or vibrates all by itself, neither doing or feeling exclusively, neither active nor passive' (Morton, 2016, p. 180). 


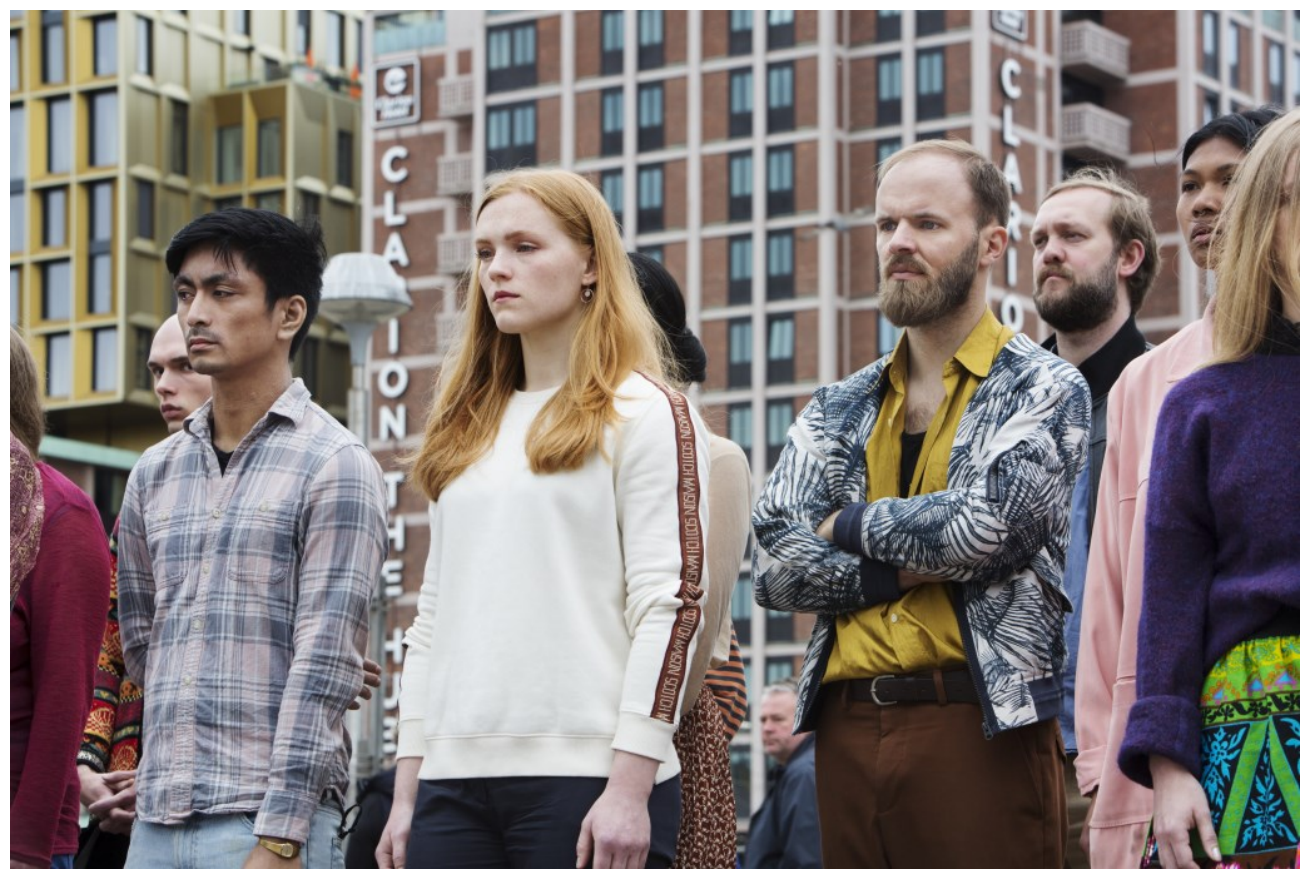

Figure 10. Carole Douillard: The Viewers, 2019, a performance at Oslo Central Station. Photo: Inger Marie Grini. Courtesy of Carole Douillard/ Oslobiennalen First Edition 2019-2024

The presence of The Viewers changes the space concretely, because they represent something strange, it is an act of 'stranging', to use Eleonora Fabião's concept. As material, flesh, blood, and bones, these bodies also represent alterity, because they behave differently from what is expected in a public space. Through their alterity and strangeness, the group already changes the dramaturgy of the space, introducing a different use of time in a place like this. Slowing down produces other narratives, opens up other possibilities for experiencing a public space. In my encounter with The Viewers, I am reshaped or perhaps reorganised, in the same way as Carole Douillard's initiative has reshaped the participating bodies and thus their surroundings. Bodies and buildings start to dance together in a common rhythm. All of us take part in shaping each other and the place, in the same way as we are all are shaped by the temporary assemblages we are a part of.

A dramaturgy never stays the same because things, buildings, thoughts, conversations, dreams and texts are all fluid and have their own temporality. The world consists of things that assemble and constantly tune into other things, creating other realities. None of them are more real than others. We can never grasp the material reality and its potentialities, the real is not accessible in its entirety, according to $\mathrm{OOO}$. 
Camilla Eeg-Tverbakk. Dramaturgies of reality - shaping and being shaped by things

\section{Sustainable futures}

Even if none of the works I discuss in this article directly concern issues of sustainability, climate questions or topics relating to ecology, I would still argue that they operate within a paradigm of sustainable art practices. All of them work with 'found material', things that already existed before they became part of a work of art. The way I choose to read them and discuss them in this article, from the perspective of object-oriented ontology and the ethics of things, contains a critique of the Anthropocene, and aspires to a more sustainable future for all beings, sentient and non-sentient. From a deep concern with finding other ways of understanding relations between humans and other things, developing new ways to coexist, I hope to inspire people to experience works of art in public spaces as more situated, where the viewer becomes entangled in the situation and experience, both shaping and being shaped simultaneously. Silvia Benso (2000) is concerned with the ethics of relating to things as alterity, where, through patience and tender touch, we can access the unknown of things, their thingliness reminding us of our own temporality. Writing about tuning in his book Being Ecological (Morton, 2018), Timothy Morton is concerned with how art plays an important role in understanding our relationship to non-humans, not through mimicking but by tuning into the unseeable and ungraspable nature of things with more or less intimacy, that is seeing the future or futurality (Morton, 2018, p.124). To him, art functions as 'a sort of gate through which you can glimpse the unconditioned futurality that is a possibility conditioned for predictable futures' (Morton 2018, p.127). As already mentioned, dramaturgy is about how to organise time and space. The three works that I have tuned into all call for a different temporality, and 'realizing there are lots of different temporality formats is basically what ecological awareness is' (Morton, 2018, p.127-128).

\section{About the author}

Camilla Eeg-Tverbakk is professor in Drama and Theatre at Oslo Metropolitan University, and a practicing dramaturg. Her research centers around concepts of new dramaturgy, documentary theatre practice, ethics in artistic research, and interdisciplinarity in the arts. Her work lies between practice and theory, and she has contributed to anthologies and periodicals, as well as co-editing and edited books on contemporary dance, performance and performing pedagogies.

\section{Photo rights}


Camilla Eeg-Tverbakk. Dramaturgies of reality - shaping and being shaped by things

House of Commons: Niklas Lello

Movimento HO, courtesy of the artist

The Viewers: Inger Marie Grini/ Oslobiennalen, First Edition (2019-2024)

\section{References}

Bellisco, M., Cifuentes, M. J. \& Ecija, A. (Eds.). (2011). Rethinking Dramaturgy, Errancy and Transformation. Centro Párraga CENDEAC.

Benso, S. (2000). The Face of Things, A Different Side of Ethics. SUNY Press.

Eeg-Tverbakk, C. (2018). Kollektivets dramaturgi. In Pettersen A.T. \& Skolseg, R. (Eds.). Innside/ Utside. Oslo: VERK produksjoner og Uten Tittel.

Fabião, E. (2018). Call me Text, Just Text *. In Studies in Gender and Sexuality, 19 (1), 55-68.

https://www.tandfonline.com/doi/abs/10.1080/15240657.2018.1421304

Harman, G. (2002). Tool-Being, Heidegger and the Metaphysics of Objects. Peru Illinois: Carus Publishing Company.

Harman, G. (2010). Towards Speculative Realism. Winchester and Washington: Zero Books.

Heidegger, M. (2001/1971). Poetry, Language, Thought. New York: Perennial Classics.

Kwon, M. (2002). One Place After Another, Site Specific Art and Locational Identity. MIT Press. https://doi.org/10.7551/mitpress/5138.001.0001

Lepecki, A. (2014). Variations on Things and Performance. In Solomon, N. (ed.). Dance: An Anthology. Les Presses Du Reel.

Lepecki, A. (2016). Singularities, Dance in the Age of Performance. Routledge. https://doi.org/10.4324/9781315694948

Morton, T. (2013). Realist Magic, Objects, Ontology, Causality. Open Humanities Press.

Morton, T. (2016). Appearance is War. In Brouwer, J, Spuybroek, L. \& Van Tuinen, S. (Eds.) The War of Appearances: Transparency, Opacity, Radiance. (p. 167182) Rotterdam: V2_Publishing

Morton, T. (2018). Being Ecological. Pelican Books. https://doi.org/10.7551/mitpress/11638.001.0001

Romanska, M. (Ed.). (2016). The Routledge Companion to Dramaturgy. Routledge.

Sánchez, J. (2011). Dramaturgy in an Expanded Field. In Bellisco, M., Cifuentes, M. J. \& Ecija, A. (Eds.). Rethinking Dramatugry, Errancy and Transformation. (p. 39-56) Centro Párraga CENDEAC 
Camilla Eeg-Tverbakk. Dramaturgies of reality - shaping and being shaped by things

Taussig, M. (2011). I Swear I Saw This. Chicago and London: University of Chicago Press. https://doi.org/10.7208/chicago/9780226789842.001.0001

Trencsényi, K. \& Cochrane, B. (Eds.). (2014). New Dramaturgy, International Perspectives on Theory and Practice, Methuen Drama.

Turner, C., \& Behrndt, S.K. (2008). Dramaturgy and Performance, Palgrave Macmillan 